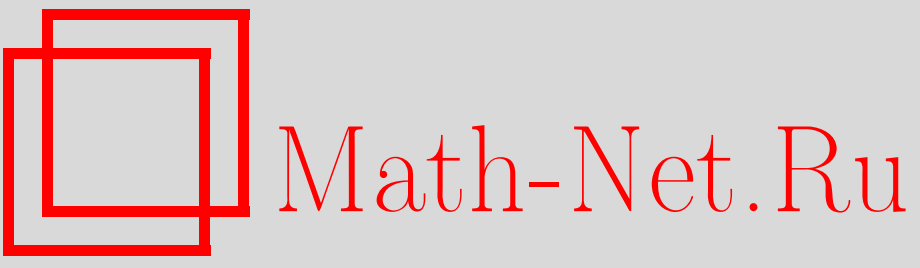

Памяти Роланда Львовича Добрушина, УМH, 1997, том 52, выпуск 2, 4

DOI: https://doi.org/10.4213/rm1730

Использование Общероссийского математического портала Math-Net.Ru подразумевает, что вы прочитали и согласны с пользовательским соглашением

http://www.mathnet.ru/rus/agreement

Параметры загрузки:

IP : 3.85 .73 .92

26 апреля 2023 г., 18:20:04 


\section{ПАМЯТИ РОЛАНДА ЛЬВОВИЧА ДОБРУШИНА}

Со смертью Р. Л. Добрушина мировое математическое сообшество понесло тяжелую утрату. Редакция "Успехов Математических Наук" посвящает этот том памяти Роланда Львовича.

Здесь помещены краткие очерки, освещающие различные области его математической деятельности и написанные людьми, близко его знавшими. Кроме этих очерков, том содержит научные статьи, тематика которых близка математическим интересам Р. Л. Добрушина, и чьи авторы имели с ним частые научные контакты.

Мы хотим также отметить, что в настоящее время в научных изданиях уже появились мемориальные статьи о Р. Л. Добрушине: большая статья коллектива авторов в журнале “Проблемы передачи информации" (т. 32, № 3, 1996), в которой подробно освешено его научное творчество и приведена полная библиография его научных работ. В “Journal of Applied Mathematics and Stochastic Analysis” (v. 9, № 4, 1996) также появилась статья с подробным анализом математической деятельности Р. Л. Добрушина. Аналогичная статья вьшла в журнале "Теория вероятностей и ееприменения" (т. 41, № 1, 1996). Ряд коротких некрологов появился и в других журналах, в частности, в журнале Американского математического общества "Notice". Готовится к изданию мемориальный том журнала "Communications in Mathematical Physics", посвяшенньй Р. Л. Добрушину.

В апреле прошлого года в память о Р. Л. Добрушине прошло мемориальное заседание Московского Математического общества, в сентябре в Вене в Институте Шрёдингера, где последние два года работал Р. Л. Добрушин, состоялась научная конференщия, посвященная ему. Аналогичная конференция была проведена под Парижем по инициативе французского Института INRIA. 